\title{
Do new neurons have a functional role in the adult hippocampus?
}

\author{
Heather A. Cameron • Brian R. Christie
}

Received: 14 June 2006 / Accepted: 29 December 2006 / Published online: 19 April 2007

(C) Springer Science + Business Media, LLC 2007

\begin{abstract}
Although the existence of adult neurogenesis in the dentate gyrus is now almost universally accepted, it is not widely established that the new neurons perform any necessary function. However, evidence indicates that the number of new neurons that are generated and form functional synapses is clearly large enough to impact the circuitry of the hippocampus. Additionally, several treatments show parallel effects on neurogenesis and hippocampus-dependent behaviors, suggesting a possible causal relationship between new neurons and hippocampal function. Most importantly, several recent studies have found that killing or inhibiting proliferation of granule cell precursors impairs performance on several hippocampusdependent tasks. Control experiments showing no impairment on slightly different behavioral tests suggest that the deficits are highly specific and unlikely to result from side effects of the neurogenesis-inhibiting treatments. In summary, the evidence to date strongly suggests that adult neurogenesis in the dentate gyrus plays a vital role in hippocampal function.
\end{abstract}

Keywords hippocampus $\cdot$ dentate gyrus $\cdot$ behavior . neurogenesis - granule cells

H. A. Cameron $(\bowtie)$

Unit on Neuroplasticity, Mood and Anxiety Disorders Program, Department of Health and Human Services,

National Institute of Mental Health, National Institutes of Health, 35/3C915, 35 Lincoln Dr, Bethesda, Maryland 20892, USA

e-mail: heathercameron@mail.nih.gov

B. R. Christie

Department of Psychology, University of British Columbia,

Vancouver, British Columbia, Canada
More than 40 years after it was first discovered, the fact that new neurons continue to be added to the dentate gyrus in adult mammals has become almost universally accepted [1, $14,30]$. Despite this growth in recognition that neurogenesis does in fact occur, there is still a great deal of uncertainty as to whether these new neurons play any real role in hippocampal function $[44,53]$. One could argue that neurogenesis is not required for normal brain function, and that it instead represents a vestigial process left over from early development with no real function. However, there has been a substantial accumulation of indirect evidence that adult neurogenesis affects the functioning of the hippocampus. More importantly, a handful of recent studies provide direct evidence that neurogenesis does, in fact, play an important role in hippocampus-dependent behavior.

For adult neurogenesis to play a vital role in hippocampal function, it should show several key attributes. First, the process must generate enough new neurons to potentially impact the circuitry. Second, these new neurons must form proper connections with the existing hippocampal circuitry. Third, new neuron production should be increased by factors that improve learning and inhibited by factors that negatively impact hippocampus-dependent behavior. Finally, directly inhibiting adult neurogenesis should impair hippocampal function, whereas increasing neurogenesis should improve hippocampus-dependent abilities. We will discuss evidence for each of these below.

\section{Adult neurogenesis produces large numbers of long-lasting granule cells}

It is unclear how many new neurons need to be produced to have an impact on the function of the dentate gyrus. Although the size of the granule cell population is quite 
large (2.4 million in rats and 0.98 million in mice $[9,86])$, studies using immediate-early genes as markers of activated neurons show that spatial exploration activates $\sim 35 \%$ of CA1 pyramidal neurons and $\sim 25 \%$ of CA3 pyramidal neurons, but less than $\sim 2 \%$ of granule cells [67]. This sparse activation of granule cells is thought to reflect sparse encoding in the dentate gyrus that in turn allows for large numbers of nonoverlapping memory traces [35, 75]. Because small numbers of granule cells are activated by a given experience, it follows that small numbers of new granule cells could potentially play an important role in dentate gyrus function. The number of young neurons in the dentate gyrus at a given time $[13,68]$ is relatively similar to the number of granule cells activated by behavior tasks [67, 85]. Approximately half of these young neurons survive to maturity in standard laboratory conditions [16], but hippocampus-dependent learning tasks can increase their survival [29, 42, 62]. Taken together, these findings seem to indicate that there are enough new neurons to potentially affect hippocampal function.

\section{New neurons integrate into the hippocampus}

For new granule cells to function as neurons, they must integrate into the hippocampal network. This condition is necessary, although it is not, of course, sufficient to demonstrate that they serve a behavioral function. Activation of new granule neurons by physiologically appropriate stimuli has not yet been demonstrated, as it has in the birdsong system [66]. However, several recent studies using acute slice preparations have shown that new granule cells do have functional synapses. The earliest active synaptic inputs onto new granule cells are those responsive to GABA, which is excitatory in the young granule cells as it is in the developing brain [3, 24, 28, 36, 64, 65, 80]. Functional glutamatergic synapses appear after GABAergic synapses $[24,28,72]$. The specific timing of development of synapses has been examined in retrovirally labeled granule cells, where synaptic GABAergic responses could be evoked in approximately $50 \%$ of 7-day-old granule cells, and synaptic glutamatergic responses could be evoked in approximately $65 \%$ of 14-day-old granule cells [28]. Interestingly, synaptic responses in young granule cells are more easily potentiated than those in older granule cells $[72,76]$. Young granule cells extend axons into the CA3 region [32, 33] and fire action potentials [64, 83]. The technical difficulty associated with finding synaptically paired granule cells and CA3 pyramidal cells has made it impossible so far to examine synaptic output of young granule cells. However, the extension of axons by and development of synapses onto new granule cells suggests that they do become fully integrated into the network, probably within 4 to 5 weeks of their birth.

\section{Parallel effects on neurogenesis and learning/memory}

If new granule neurons play an important role in hippocampal function, then it follows that gain or loss of new neurons should alter function. However, there are two issues that make this idea less than straightforward to test. The first is that the function of the hippocampus itself is still under debate (see text box), and the function of the dentate gyrus specifically in most tasks is unclear. Second, the relationship between the function of a given neuronal population and the number of neurons in that population is not likely to be linear. Lesion studies show that nearcomplete removal of the hippocampus is required to produce detectable impairment in several hippocampusdependent tasks, so even if the loss of a considerable number of new neurons does not produce an effect, this does not mean they are not functional. Conversely, adding more new neurons might not significantly improve hippocampal function, because the dentate gyrus may normally produce all of the new neurons it needs to function optimally or because other brain regions involved in a given task limit behavioral improvement.

Nonetheless, evidence for parallel effects on the rate of neurogenesis and behavior in learning and memory tasks in several experimental paradigms is at least consistent with a causal relationship (also see discussion by [41]). Mouse strains that have higher numbers of new granule cells learn better in the Morris water maze [37], and wild-living rodent strains with higher rates of neurogenesis use more spatially complex arrangements of food storage sites and are better at learning a rewarded place learning task [7, 27]. In both of these cases, the rates of adult neurogenesis may reflect changes to granule cell precursors during development, so it is possible that developmental changes are responsible for the differential spatial abilities. However, similar changes are also seen after several experimental manipulations that begin in adulthood. Wheel running and housing enrichment both increase neurogenesis and improve learning. Voluntary and forced wheel running increase granule cell precursor proliferation $[10,21,25,40,79,81,82]$, and improve performance on hippocampus-dependent memory tasks [4, 26, 82]. Exercise also appears to alleviate symptoms of depression in humans, consistent with a link between neurogenesis and depressive illness [23]. Similarly, housing in an enriched environment increases young granule cell survival and improves learning in several tasks [38, 60]. However, situations have been found in which the effects of these manipulations on learning and neurogenesis can be dissociated: mice bred for increased running show high 


\section{The function of the hippocampus}

That the hippocampus plays a role in certain forms of learning and memory has been apparent since the initial reports of severe amnesia in patient H.M. [51]. Following bilateral removal of the medial temporal lobes that included the majority of his hippocampal formation, H.M. became severely impaired in his ability to create new episodic, or autobiographical, memories, although he retained his ability to complete tasks requiring recall from working and procedural memory [52]. Several other patients with similar memory impairments following hippocampal damage or atrophy have since been documented [78]. The initial attempts to develop animal models failed to demonstrate a similar form of memory impairment after hippocampal damage in rats and monkeys, but it was not clear whether this reflected a very different role for the hippocampus in non-human species or a lack of suitable, e.g., non-verbal, tests [34]. It was not until the development of spatial memory tasks that the effects of hippocampal lesions in rodents began to emerge [58], leading to the idea that in rodents, the hippocampus primarily subserves memory for places $[12,59,61]$. Further support for an important role of the hippocampus in spatial memory comes from the fact that the hippocampus contains neurons, so-called "place cells", that respond to spatial locations [43]. However, strong evidence now points to the involvement of the rodent hippocampus in several forms of completely non-spatial associative memory [2, 31, 48], and suggest that the primary role of the hippocampus in all mammalian species may be to rapidly encode sequences of events $[22,57]$. In addition to its role in episodic and spatial memory, several lines of evidence suggest that the hippocampus may also play a role in depressive illness [19, 71].

levels of neurogenesis but no learning improvement [69], whereas enrichment-induced changes in an anxiety test, novelty-suppressed feeding, and in spatial learning in the Morris water maze are observed even in the absence of new granule cells [50].

Stress and soft-food diets both inhibit neurogenesis and impair hippocampus-dependent learning. Stress and stress hormones strongly inhibit granule cell birth and decrease survival (reviewed in [54]) and impair hippocampusdependent learning [39, 41, 45]. Interestingly, soft-food diets and the resulting decrease in chewing also lead to decreased neurogenesis $[5,55]$ and impaired hippocampusdependent learning $[47,63]$, possibly resulting from decreased cerebral blood flow and release of growth factors into the brain.

Aging also decreases neurogenesis and is associated with impairment in hippocampus-dependent learning. Decreased cell proliferation and reduced numbers of immature neurons are associated with deficits in hippocampus-dependent behavior in old rats [84]. Two studies have found significant correlations between cell proliferation and spatial learning within the same group of rats [17, 18]. However, other studies have found no correlation, or even a negative correlation, between neurogenesis and learning in aged rats $[8,15,49]$. Because of the differences in the timing of cell labeling with regard to behavioral testing and in the age of the cells examined (i.e., cells dividing after learning versus very young neurons versus mature neu- rons), these studies are not necessarily inconsistent with each other but do suggest a complex relationship between neurogenesis and hippocampal function in aged animals.

Although the large number of these associations is suggestive of a relationship between neurogenesis and hippocampal function, these correlations provide no direct evidence of a causal relationship between new neurons and behavior. Many of the manipulations have known effects in other brain regions, such as neocortex (e.g., enriched environment and soft-food diet), that contribute to performance even on "hippocampus-dependent" behavior tasks. Others (e.g., stress) have almost immediate effects on hippocampus-dependent learning, which are not likely to result from changes in neurogenesis. Strong evidence for a causal relationship between neurogenesis and hippocampal function can come only from manipulations that directly and specifically alter the production or activation of new granule cells.

\section{Functional effects of killing neuronal precursors}

Two approaches have been used to directly address the function of new neurons in the adult hippocampus. Both eliminate new neurons by preventing their birth. The chemical antimitotic agent methylazoxymethanol acetate (MAM) reversibly stops granule cell precursors from dividing. However, it also inhibits cell division indiscrim- 
inately throughout the rest of the brain as well as in the body when given systemically as in these studies. Presumably because of these nonspecific effects, MAM can cause weight loss, decreased locomotor activity, and piloerection/ dirty fur associated with stress and poor health [20, 74]. Ionizing radiation kills dividing granule cell precursor cells [89]. Direct effects on other dividing cells can be confined to the head and even, with shielding, to a vertical or horizontal slab within the brain that contains the hippocampus. However, even when irradiation is confined to the head, it causes weight loss [77], which may reflect overall ill health that could potentially cause behavior changes unrelated to loss of new granule cells. Additionally, irradiation can cause hippocampal inflammation, possibly resulting from or causing damage to other hippocampal cells [56]. However, small changes to the treatment regimens for both methods can minimize these side effects. When used at low dose, MAM kills $75 \%$ of granule cell precursors without causing weight loss or other outward signs of general ill-health [73, 74]. Likewise, the inflammation associated with irradiation can be avoided by choosing barbiturate anesthetics rather than ketamine during the irradiation procedure [89]. Although side effects may not be completely eliminated even with these modified procedures, potential nonspecificity can also be controlled for experimentally by showing normal performance on tasks that require similar sensory and motor skills but make different demands on the hippocampus. As described below, impairment is not found in delay eyeblink classical conditioning (using MAM), simple context fear conditioning (MAM), or Morris water maze acquisition (irradiation), arguing that these treatments do not cause widespread, nonspecific behavioral effects. Therefore, although it is very difficult to completely rule out the possibility of nonspecific treatment effects, when side effects are minimized and controlled for, MAM and irradiation are both good tools for directly addressing the question of new granule neuron function (Table 1).

Shors et al. [73, 74] gave low-dose MAM for 2 weeks, which resulted in a $75 \%$ loss of granule cell birth. They found that MAM-treated rats were impaired on two hippocampus-dependent learning and memory tasks: trace eyeblink conditioning and trace cued fear conditioning. Importantly, the nonhippocampus dependent "delay" version of the eyeblink task, which differs only in the temporal association of the conditioned and unconditioned stimuli, was unaffected. Delay-dependent effects have also been found in the novel object recognition and nonmatch to sample tests. Decreased memory for a novel object was seen in MAM-treated animals at 24- or 48-h delay time points [11], while no impairment was seen in MAM- or irradiationtreated animals after 15-min or 1-h delay [11, 46]. Similarly, irradiated rats were impaired on a delayed nonmatch-tosample cued water maze task with 2- and 4-min delay times, but not with 0 - or 1-min delay [88]. These delay-dependent effects are typical of hippocampal deficits; effects of

Table 1 Experiments testing the behavioral effects of loss of new granule neurons in the adult hippocampus

\begin{tabular}{|c|c|c|c|c|c|}
\hline Task & Details & Impaired & Method & Control task ${ }^{\mathrm{a}}$ & Reference \\
\hline $\begin{array}{l}\text { Trace eyeblink classical } \\
\text { conditioning }\end{array}$ & & Yes & $\begin{array}{l}\text { MAM, } 5 \mathrm{mg} / \mathrm{kg} \times \\
14 \text { days }\end{array}$ & Delay version of task & {$[74]$} \\
\hline Trace-cued fear conditioning & & Yes & $\begin{array}{l}\text { MAM, } 7 \mathrm{mg} / \mathrm{kg} \times \\
14 \text { days }\end{array}$ & - & {$[73]$} \\
\hline T-maze place recognition & 90 s delay & Yes & IRR, 3 Gy $\times 8$ days & $\begin{array}{l}\text { Novel object recognition } \\
\text { (15 min delay) }\end{array}$ & {$[46]$} \\
\hline Novel object recognition & 1-2 days delay & Yes & $\begin{array}{l}\text { MAM, } 5 \mathrm{mg} / \mathrm{kg} \times \\
14 \text { days }\end{array}$ & Same task with $1 \mathrm{~h}$ delay & {$[11]$} \\
\hline Delayed nonmatch to sample & $2-4$ min delay & Yes & $\begin{array}{l}\text { IRR, } 7.5 \text { or } 10 \mathrm{~Gy} \times \\
2 \text { days }\end{array}$ & Same task with 0 or 1 min delay & {$[88]$} \\
\hline Contextual fear conditioning & $\begin{array}{l}\text { Transparent } \\
\text { chamber }\end{array}$ & Yes & $\begin{array}{l}\text { IRR, } 7.5 \text { or } 10 \mathrm{~Gy} \times \\
2 \text { days }\end{array}$ & Cued fear conditioning & {$[88]$} \\
\hline Contextual fear conditioning & $\begin{array}{l}\text { Closed } \\
\text { chamber }\end{array}$ & No & $\begin{array}{l}\text { MAM, } 7 \mathrm{mg} / \mathrm{kg} \times \\
14 \text { days }\end{array}$ & - & {$[73]$} \\
\hline Morris water maze, acquisition & & No & $\begin{array}{l}\text { MAM and IRR } \\
\text { (see refs) }\end{array}$ & - & $\begin{array}{r}{[46,50} \\
73,77]\end{array}$ \\
\hline $\begin{array}{l}\text { Morris water maze, long-term } \\
\text { memory }\end{array}$ & & Yes & IRR, 10 Gy $\times 2$ days & $\begin{array}{l}\text { MWM acquisition; long-term } \\
\text { memory in cued task }\end{array}$ & {$[77]$} \\
\hline $\begin{array}{l}\text { Novelty-suppressed feeding } \\
\text { (anxiety/depression) }\end{array}$ & & No & $\begin{array}{l}\text { IRR, } 5 \text { Gy } \times 3 \text { days, } \\
\text { ketamine }\end{array}$ & - & {$[50,70]$} \\
\hline
\end{tabular}

${ }^{a}$ Control task indicates similar task that showed no impairment in the same study. 
complete hippocampal lesion are usually only evident in tasks with long retention times [31, 87]. Performance in contextual fear conditioning was impaired by loss of young granule cells in one study [88], but not in another [73]. These two studies used different methods of decreasing neurogenesis (irradiation and MAM, respectively), but it has been suggested that a more important difference may be the use of external cues to make the context complex and increase the demand on the hippocampus [88]. In a hippocampusdependent test of anxiety-like behavior, novelty-suppressed feeding, irradiation had no effect on behavior, but did prevent antidepressants from altering behavior in this task $[50,70]$, suggesting that new neurons do not play a primary role in anxiety-like behavior, but may affect performance of this task under some conditions. Spatial memory has been shown to be impaired in a place recognition T-maze task [46]. Interestingly, no impairment has been found with either MAM or irradiation in spatial learning in the classic Morris water maze task $[46,50,73,77]$. However, one study went further, testing long-term memory for the platform location at several delay intervals, and found that control rats showed no decline in memory for the platform location following a 2week retention interval, while irradiated rats' performance dropped to chance levels [77].

Taken together, these MAM and irradiation studies indicate that new neurons are required for at least some aspects of hippocampal function. Behavioral impairment has been found in a wide variety of both spatial and nonspatial hippocampus-dependent tasks. In nearly all cases, the versions of tasks showing no deficit-delay eyeblink conditioning, short-delay nonmatch to sample, short-delay novel object recognition, and simple context fear conditioning - do not require an intact hippocampus, while tasks requiring the hippocampus are impaired by loss of new neurons. That is, loss of new neurons has the same effect as loss of the entire hippocampus in these tasks. One finding appears to be an exception to this rule [77], and is therefore particularly interesting. Only long-term reference memory for, and not acquisition of, platform location was found to be impaired in irradiated rats, even though acquisition in the Morris water maze requires the hippocampus [6]. This dissociation may provide the first hint at the specific role of the new neurons within the hippocampus. Although this specific role is not yet clear, the impairments found in several studies, using two different methods to inhibit neurogenesis and several different behavior tasks, clearly indicate an important role for new granule neurons in learning and memory.

Acknowledgments Support from the Intramural Research Program of the NIH, NIMH (Z01-MH002784) to H.A.C. is gratefully acknowledged. Support from CIHR, NSERC, the BC Ministry of
Children and Development, and the Human Early Learning Project (HELP) to B.R.C. is gratefully acknowledged. B.R.C. is the BMO Young Investigator at UBC Hospital.

\section{References}

1. Abrous DN, Koehl M, Le Moal M (2005) Adult neurogenesis: from precursors to network and physiology. Physiol Rev 85:523569

2. Alvarez P, Lipton PA, Melrose R, Eichenbaum H (2001) Differential effects of damage within the hippocampal region on memory for a natural, nonspatial odor-odor association. Learn Mem 8:79-86

3. Ambrogini P, Minelli A, Lattanzi D, Ciuffoli S, Fanelli M, Cuppini R (2006) Synaptically silent immature neurons show gaba and glutamate receptor-mediated currents in adult rat dentate gyrus. Arch Ital Biol 144:115-126

4. Anderson BJ, Rapp DN, Baek DH, McCloskey DP, CoburnLitvak PS, Robinson JK (2000) Exercise influences spatial learning in the radial arm maze. Physiol Behav 70:425-429

5. Aoki H, Kimoto K, Hori N, Toyoda M (2005) Cell proliferation in the dentate gyrus of rat hippocampus is inhibited by soft diet feeding. Gerontology 51:369-374

6. Bannerman DM, Good MA, Butcher SP, Ramsay M, Morris RG (1995) Distinct components of spatial learning revealed by prior training and NMDA receptor blockade. Nature 378:182-186

7. Barker JM, Wojtowicz JM, Boonstra R (2005) Where's my dinner? Adult neurogenesis in free-living food-storing rodents. Genes Brain Behav 4:89-98

8. Bizon JL, Lee HJ, Gallagher M (2004) Neurogenesis in a rat model of age-related cognitive decline. Aging Cell 3:227-234

9. Bonthius DJ, McKim R, Koele L, Harb H, Karacay B, Mahoney J, Pantazis NJ (2004) Use of frozen sections to determine neuronal number in the murine hippocampus and neocortex using the optical dissector and optical fractionator. Brain Res Brain Res Protoc $14: 45-57$

10. Brown J, Cooper-Kuhn CM, Kempermann G, Van Praag H, Winkler J, Gage FH, Kuhn HG (2003) Enriched environment and physical activity stimulate hippocampal but not olfactory bulb neurogenesis. Eur J Neurosci 17:2042-2046

11. Bruel-Jungerman E, Laroche S, Rampon C (2005) New neurons in the dentate gyrus are involved in the expression of enhanced longterm memory following environmental enrichment. Eur J Neurosci 21:513-521

12. Burgess N, Becker S, King JA, O'Keefe J (2001) Memory for events and their spatial context: models and experiments. Philos Trans R Soc Lond B Biol Sci 356:1493-1503

13. Cameron HA, McKay RD (2001) Adult neurogenesis produces a large pool of new granule cells in the dentate gyrus. J Comp Neurol 435:406-417

14. Christie BR, Cameron HA (2006) Neurogenesis in the adult hippocampus. Hippocampus 16:199-207

15. Cuppini R, Bucherelli C, Ambrogini P, Ciuffoli S, Orsini L, Ferri P, Baldi E (2006) Age-related naturally occurring depression of hippocampal neurogenesis does not affect trace fear conditioning. Hippocampus 16:141-148

16. Dayer AG, Ford AA, Cleaver KM, Yassaee M, Cameron HA (2003) Short-term and long-term survival of new neurons in the rat dentate gyrus. J Comp Neurol 460:563-572

17. Drapeau E, Mayo W, Aurousseau C, Le Moal M, Piazza PV, Abrous DN (2003) Spatial memory performances of aged rats in the water maze predict levels of hippocampal neurogenesis. Proc Natl Acad Sci U S A 100:14385-14390 
18. Driscoll I, Howard SR, Stone JC, Monfils MH, Tomanek B, Brooks WM, Sutherland RJ (2006) The aging hippocampus: a multi-level analysis in the rat. Neuroscience 139:1173-1185

19. Duman RS (2004) Depression: a case of neuronal life and death? Biol Psychiatry 56:140-145

20. Dupret D, Montaron MF, Drapeau E, Aurousseau C, Le Moal M, Piazza PV, Abrous DN (2005) Methylazoxymethanol acetate does not fully block cell genesis in the young and aged dentate gyrus. Eur J Neurosci 22:778-783

21. Eadie BD, Redila VA, Christie BR (2005) Voluntary exercise alters the cytoarchitecture of the adult dentate gyrus by increasing cellular proliferation, dendritic complexity, and spine density. J Comp Neurol 486:39-47

22. Eichenbaum H (2004) Hippocampus: cognitive processes and neural representations that underlie declarative memory. Neuron 44:109-120

23. Ernst C, Olson AK, Pinel JP, Lam RW, Christie BR (2006) Antidepressant effects of exercise: evidence for an adult-neurogenesis hypothesis? J Psychiatry Neurosci 31:84-92

24. Esposito MS, Piatti VC, Laplagne DA, Morgenstern NA, Ferrari CC, Pitossi FJ, Schinder AF (2005) Neuronal differentiation in the adult hippocampus recapitulates embryonic development. J Neurosci 25:10074-10086

25. Farmer J, Zhao X, van Praag H, Wodtke K, Gage FH, Christie BR (2004) Effects of voluntary exercise on synaptic plasticity and gene expression in the dentate gyrus of adult male SpragueDawley rats in vivo. Neuroscience 124:71-79

26. Fordyce DE, Wehner JM (1993) Physical activity enhances spatial learning performance with an associated alteration in hippocampal protein kinase $\mathrm{C}$ activity in $\mathrm{C} 57 \mathrm{BL} / 6$ and $\mathrm{DBA} / 2$ mice. Brain Res 619:111-119

27. Galsworthy MJ, Amrein I, Kuptsov PA, Poletaeva, II, Zinn P, Rau A, Vyssotski A, Lipp HP (2005) A comparison of wild-caught wood mice and bank voles in the Intellicage: assessing exploration, daily activity patterns and place learning paradigms. Behav Brain Res 157:211-217

28. Ge S, Goh EL, Sailor KA, Kitabatake Y, Ming GL, Song H (2006) GABA regulates synaptic integration of newly generated neurons in the adult brain. Nature 439:589-593

29. Gould E, Beylin A, Tanapat P, Reeves A, Shors TJ (1999) Learning enhances adult neurogenesis in the hippocampal formation. Nat Neurosci 2:260-265

30. Gross CG (2000) Neurogenesis in the adult brain: death of a dogma. Nat Rev Neurosci 1:67-73

31. Hammond RS, Tull LE, Stackman RW (2004) On the delaydependent involvement of the hippocampus in object recognition memory. Neurobiol Learn Mem 82:26-34

32. Hastings NB, Gould E (1999) Rapid extension of axons into the CA3 region by adult-generated granule cells. J Comp Neurol 413:146-154

33. Hastings NB, Seth MI, Tanapat P, Rydel TA, Gould E (2002) Granule neurons generated during development extend divergent axon collaterals to hippocampal area CA3. J Comp Neurol 452:324-333

34. Iversen SD (1976) Do hippocampal lesions produce amnesia in animals? Int Rev Neurobiol 19:1-49

35. Jung MW, McNaughton BL (1993) Spatial selectivity of unit activity in the hippocampal granular layer. Hippocampus 3:165-182

36. Karten YJ, Jones MA, Jeurling SI, Cameron HA (2006) GABAergic signaling in young granule cells in the adult rat and mouse dentate gyrus. Hippocampus 16:312-320

37. Kempermann G, Gage FH (2002) Genetic determinants of adult hippocampal neurogenesis correlate with acquisition, but not probe trial performance, in the water maze task. Eur J Neurosci 16:129-136
38. Kempermann G, Kuhn HG, Gage FH (1997) More hippocampal neurons in adult mice living in an enriched environment. Nature 386:493-495

39. Kim JJ, Diamond DM (2002) The stressed hippocampus, synaptic plasticity and lost memories. Nat Rev Neurosci 3:453-462

40. Kim YP, Kim HB, Jang MH, Lim BV, Kim YJ, Kim H, Kim SS, Kim EH, Kim CJ (2003) Magnitude- and time-dependence of the effect of treadmill exercise on cell proliferation in the dentate gyrus of rats. Int J Sports Med 24:114-117

41. Leuner B, Gould E, Shors TJ (2006) Is there a link between adult neurogenesis and learning? Hippocampus 16:216-224

42. Leuner B, Mendolia-Loffredo S, Kozorovitskiy Y, Samburg D, Gould E, Shors TJ (2004) Learning enhances the survival of new neurons beyond the time when the hippocampus is required for memory. J Neurosci 24:7477-7481

43. Leutgeb S, Leutgeb JK, Moser MB, Moser EI (2005) Place cells, spatial maps and the population code for memory. Curr Opin Neurobiol 15:738-746

44. Lledo PM, Alonso M, Grubb MS (2006) Adult neurogenesis and functional plasticity in neuronal circuits. Nat Rev Neurosci 7:179-193

45. Luine V, Villegas M, Martinez C, McEwen BS (1994) Repeated stress causes reversible impairments of spatial memory performance. Brain Res 639:167-170

46. Madsen TM, Kristjansen PE, Bolwig TG, Wortwein G (2003) Arrested neuronal proliferation and impaired hippocampal function following fractionated brain irradiation in the adult rat. Neuroscience 119:635-642

47. Makiura T, Ikeda Y, Hirai T, Terasawa H, Hamaue N, Minami M (2000) Influence of diet and occlusal support on learning memory in rats behavioral and biochemical studies. Res Commun Mol Pathol Pharmacol 107:269-277

48. McEchron MD, Bouwmeester H, Tseng W, Weiss C, Disterhoft JF (1998) Hippocampectomy disrupts auditory trace fear conditioning and contextual fear conditioning in the rat. Hippocampus $8: 638-646$

49. Merrill DA, Karim R, Darraq M, Chiba AA, Tuszynski MH (2003) Hippocampal cell genesis does not correlate with spatial learning ability in aged rats. J Comp Neurol 459:201-207

50. Meshi D, Drew MR, Saxe M, Ansorge MS, David D, Santarelli L, Malapani C, Moore H, Hen R (2006) Hippocampal neurogenesis is not required for behavioral effects of environmental enrichment. Nat Neurosci 9:729-731

51. Milner B (1972) Disorders of learning and memory after temporal lobe lesions in man. Clin Neurosurg 19:421-446

52. Milner B (2005) The medial temporal-lobe amnesic syndrome. Psychiatr Clin North Am 28:599-611, 609

53. Ming GL, Song H (2005) Adult neurogenesis in the mammalian central nervous system. Annu Rev Neurosci 28:223-250

54. Mirescu C, Gould E (2006) Stress and adult neurogenesis. Hippocampus 16:233-238

55. Mitome M, Hasegawa T, Shirakawa T (2005) Mastication influences the survival of newly generated cells in mouse dentate gyrus. Neuroreport 16:249-252

56. Monje ML, Toda H, Palmer TD (2003) Inflammatory blockade restores adult hippocampal neurogenesis. Science 302:1760-1765

57. Morris RG, Frey U (1997) Hippocampal synaptic plasticity: role in spatial learning or the automatic recording of attended experience? Philos Trans R Soc Lond B Biol Sci 352:1489-1503

58. Morris RG, Garrud P, Rawlins JN, O'Keefe J (1982) Place navigation impaired in rats with hippocampal lesions. Nature 297:681-683

59. Nadel L, Hardt O (2004) The spatial brain. Neuropsychology 18:473-476

60. Nilsson M, Perfilieva E, Johansson U, Orwar O, Eriksson PS (1999) Enriched environment increases neurogenesis in the adult 
rat dentate gyrus and improves spatial memory. J Neurobiol 39:569-578

61. O'Keefe J, Nadel L (1978) The hippocampus as a cognitive map. Clarendon Press, Oxford

62. Olariu A, Cleaver KM, Shore LE, Brewer MD, Cameron HA (2005) A natural form of learning can increase and decrease the survival of new neurons in the dentate gyrus. Hippocampus $15: 750-762$

63. Onozuka M, Watanabe K, Nagasaki S, Jiang Y, Ozono S, Nishiyama K, Kawase T, Karasawa N, Nagatsu I (2000) Impairment of spatial memory and changes in astroglial responsiveness following loss of molar teeth in aged SAMP8 mice. Behav Brain Res 108:145-155

64. Overstreet LS, Hentges ST, Bumaschny VF, de Souza FS, Smart JL, Santangelo AM, Low MJ, Westbrook GL, Rubinstein M (2004) A transgenic marker for newly born granule cells in dentate gyrus. J Neurosci 24:3251-3259

65. Overstreet Wadiche L, Bromberg DA, Bensen AL, Westbrook GL (2005) GABAergic signaling to newborn neurons in dentate gyrus. J Neurophysiol 94:4528-4532

66. Paton JA, Nottebohm FN (1984) Neurons generated in the adult brain are recruited into functional circuits. Science 225:10461048

67. Ramirez-Amaya V, Vazdarjanova A, Mikhael D, Rosi S, Worley PF, Barnes CA (2005) Spatial exploration-induced Arc mRNA and protein expression: evidence for selective, network-specific reactivation. J Neurosci 25:1761-1768

68. Rao MS, Shetty AK (2004) Efficacy of doublecortin as a marker to analyse the absolute number and dendritic growth of newly generated neurons in the adult dentate gyrus. Eur J Neurosci 19:234-246

69. Rhodes JS, van Praag H, Jeffrey S, Girard I, Mitchell GS, Garland T, Jr., Gage FH (2003) Exercise increases hippocampal neurogenesis to high levels but does not improve spatial learning in mice bred for increased voluntary wheel running. Behav Neurosci 117:1006-1016

70. Santarelli L, Saxe M, Gross C, Surget A, Battaglia F, Dulawa S, Weisstaub N, Lee J, Duman R, Arancio O, Belzung C, Hen R (2003) Requirement of hippocampal neurogenesis for the behavioral effects of antidepressants. Science 301:805-809

71. Sapolsky RM (2004) Is impaired neurogenesis relevant to the affective symptoms of depression? Biol Psychiatry 56:137-139

72. Schmidt-Hieber C, Jonas P, Bischofberger J (2004) Enhanced synaptic plasticity in newly generated granule cells of the adult hippocampus. Nature 429:184-187

73. Shors TJ, Townsend DA, Zhao M, Kozorovitskiy Y, Gould E (2002) Neurogenesis may relate to some but not all types of hippocampal-dependent learning. Hippocampus 12:578-584

74. Shors TJ, Miesegaes G, Beylin A, Zhao M, Rydel T, Gould E
(2001) Neurogenesis in the adult is involved in the formation of trace memories. Nature 410:372-376

75. Skaggs WE, McNaughton BL (1992) Computational approaches to hippocampal function. Curr Opin Neurobiol 2:209-211

76. Snyder JS, Kee N, Wojtowicz JM (2001) Effects of adult neurogenesis on synaptic plasticity in the rat dentate gyrus. J Neurophysiol 85:2423-2431

77. Snyder JS, Hong NS, McDonald RJ, Wojtowicz JM (2005) A role for adult neurogenesis in spatial long-term memory. Neuroscience 130:843-852

78. Squire LR, Zola SM (1997) Amnesia, memory and brain systems. Philos Trans R Soc Lond B Biol Sci 352:1663-1673

79. Stranahan AM, Khalil D, Gould E (2006) Social isolation delays the positive effects of running on adult neurogenesis. Nat Neurosci 9:526-533

80. Tozuka Y, Fukuda S, Namba T, Seki T, Hisatsune T (2005) GABAergic excitation promotes neuronal differentiation in adult hippocampal progenitor cells. Neuron 47:803-815

81. van Praag H, Kempermann G, Gage FH (1999a) Running increases cell proliferation and neurogenesis in the adult mouse dentate gyrus. Nat Neurosci 2:266-270

82. van Praag H, Christie BR, Sejnowski TJ, Gage FH (1999b) Running enhances neurogenesis, learning, and long-term potentiation in mice. Proc Natl Acad Sci U S A 96:13427-13431

83. van Praag H, Schinder AF, Christie BR, Toni N, Palmer TD, Gage FH (2002) Functional neurogenesis in the adult hippocampus. Nature 415:1030-1034

84. Wati H, Kudo K, Qiao C, Kuroki T, Kanba S (2006) A decreased survival of proliferated cells in the hippocampus is associated with a decline in spatial memory in aged rats. Neurosci Lett 399:171174

85. Weitemier AZ, Ryabinin AE (2004) Subregion-specific differences in hippocampal activity between delay and trace fear conditioning: an immunohistochemical analysis. Brain Res 995:55-65

86. West MJ, Slomianka L, Gundersen HJ (1991) Unbiased stereological estimation of the total number of neurons in the subdivisions of the rat hippocampus using the optical fractionator. Anat Rec 231:482-497

87. Winocur G (1992) A comparison of normal old rats and young adult rats with lesions to the hippocampus or prefrontal cortex on a test of matching-to-sample. Neuropsychologia 30:769-781

88. Winocur G, Wojtowicz JM, Sekeres M, Snyder JS, Wang S (2006) Inhibition of neurogenesis interferes with hippocampus-dependent memory function. Hippocampus 16:296-304

89. Wojtowicz JM (2006) Irradiation as an experimental tool in studies of adult neurogenesis. Hippocampus 16:261-266 